Images In...

\title{
Post-traumatic intra-testicular haematoma may mimic a neoplasm or abscess on ultrasound
}

\author{
Brian M Boldt, David Nguyen \\ Department of Diagnostic Radiology, Madigan Army Medical Center, Tacoma, Washington, USA \\ Correspondence to Brian M Boldt, brian.boldt@amedd.army.mil
}

\section{DESCRIPTION}

We report a case of a 33-year-old man who presented with progressive painless testicular swelling. The patient reported a history of blunt testicular trauma 3 weeks prior to presentation, which resulted in minor pain and a sensation of 'popping' at the right groin. Physical exam revealed an enlarged non-tender right hemiscrotum. Labs, including chem10, white blood cells and lactic dehydrogenase were normal. $\alpha$-fetoprotein and human chorionic gonadotrophin were pending at the time of imaging.
Ultrasound examination revealed a $5.4 \times 3.2 \times 5.6 \mathrm{~cm}$ intratesticular heterogenous lesion with a peripheral hypoechoic rim (figure 1) and prominent peripheral flow with an area of minimal internal flow in the medial aspect of the right testis (figure 2-3).

Differential considerations for these imaging findings include subacute post-traumatic haematoma and fibrosis, complicated abscess, testicular carcinoma or epidermoid tumour. $^{1}$

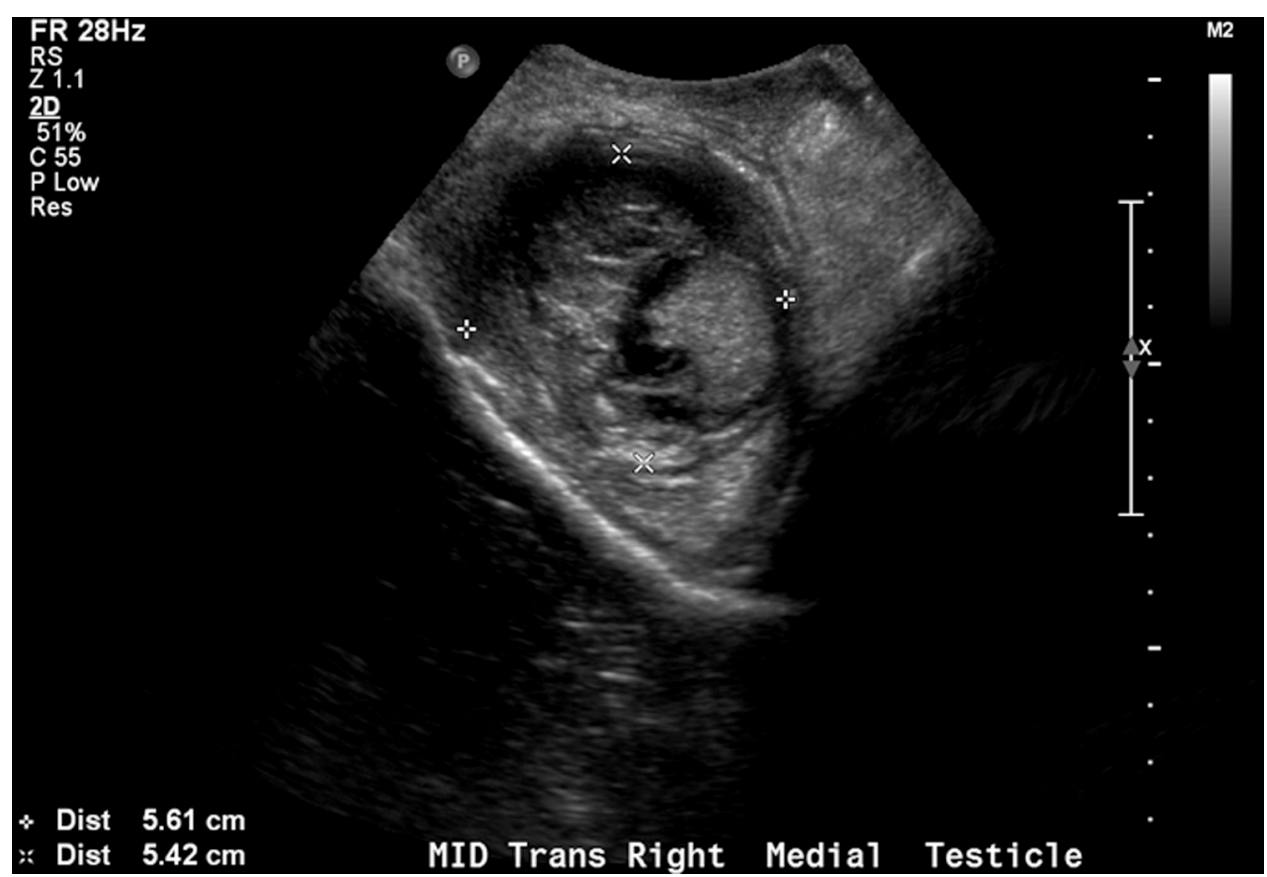

Figure 1 Longitudinal grey-scale image of the medial right testicle shows a $5.4 \times 5.6 \mathrm{~cm}$ intra-testicular heterogenous focus with a peripheral hypoechoic rim. 


\section{BMJ Case Reports}

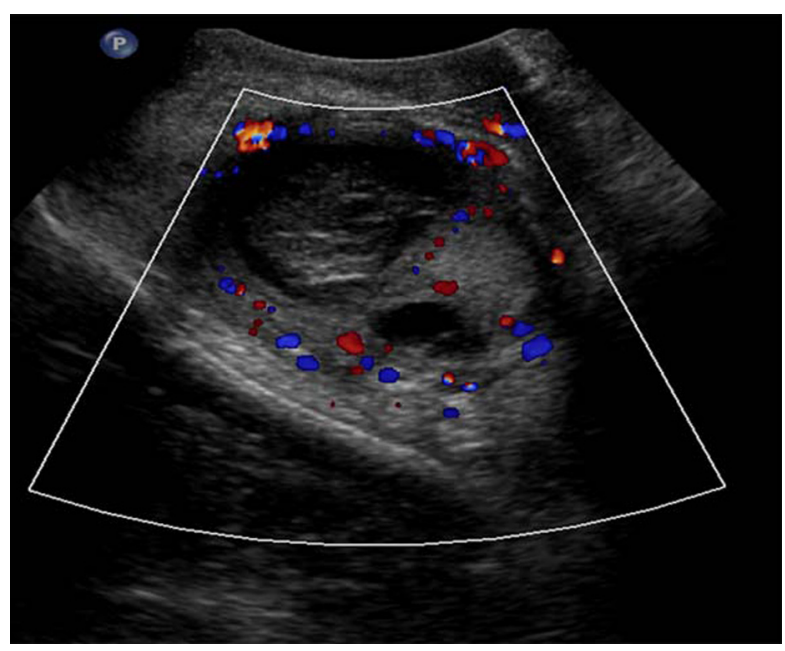

Figure 2 Longitudinal colour Doppler image of the medial right testicle shows prominent peripheral flow with minimal internal flow along the lateral aspect of the lesion.

Given these findings, malignancy could not be excluded and our patient proceeded with an elective orchiectomy. Histological evaluation revealed no malignant cells with extensive fibrotic reaction, white cell infiltrate, and a large necrotic and haemorrhagic cavity.

An important factor in interrogating an indeterminate intra-testicular lesion is colour Doppler signal. In any lesion with internal flow, testiculcar carcinoma must be placed high on the differential. These lesions should at the very least be subject to excisional biopsy. ${ }^{2}$

Although malignancy cannot be fully excluded, tumours 2 $\mathrm{cm}$ or larger are typically hypervascular and absence of internal flow is a reassuring finding. ${ }^{2}$ Some authors advocate short-term interval follow-up for lesions of this size with no colourDoppler flow and negative tumour markers. ${ }^{23}$

Competing interests None

Patient consent Obtained.

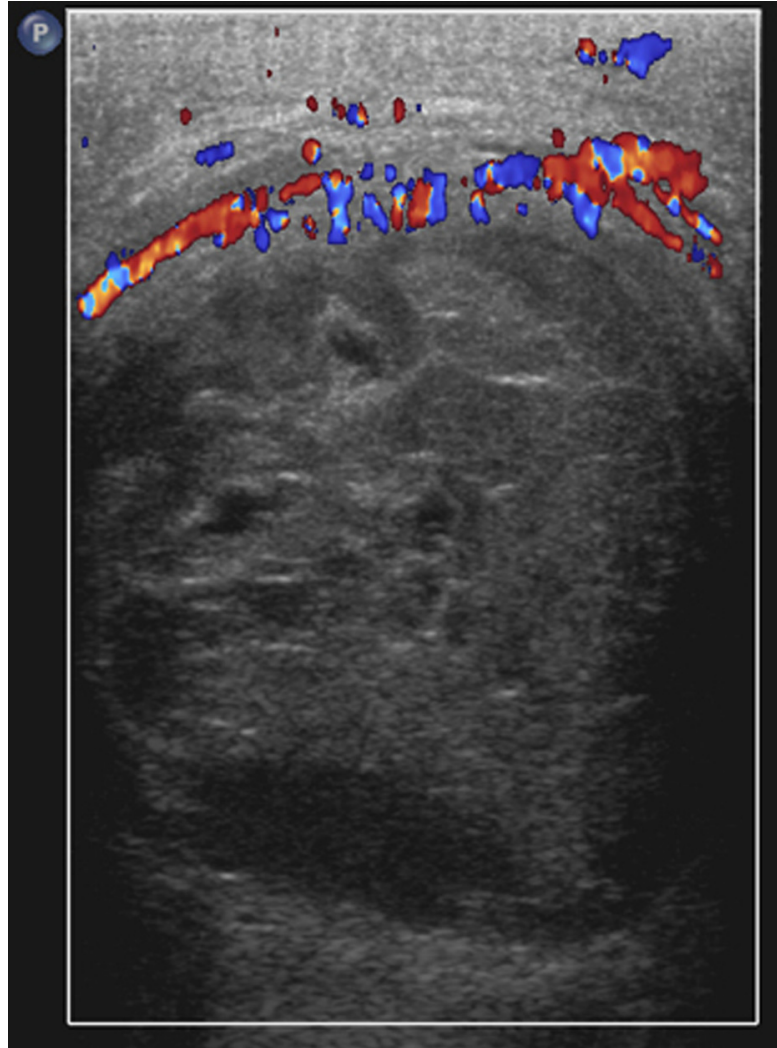

Figure 3 Transverse colour Doppler image through the middle of the lesion demonstrates peripheral flow with no appreciable internal flow.

\section{REFERENCES}

1. Stewart VR, Sidhu PS. The testis: the unusual, the rare and the bizarre. Clin Radiol 2007;62:289-302

2. Kirkham AP, Kumar P, Minhas S, et al. Targeted testicular excision biopsy: when and how should we try to avoid radical orchidectomy? Clin Radiol 2009;64:1158-65.

3. Shah A, Lung PF, Sidhu PS, et al. Re: new ultrasound techniques for imaging of the inderterminate testicular lesion may avoid surgery completely. Clin Radio/2010;65:496-7.

This pdf has been created automatically from the final edited text and images.

Copyright 2010 BMJ Publishing Group. All rights reserved. For permission to reuse any of this content visit http://group.bmj.com/group/rights-licensing/permissions.

BMJ Case Report Fellows may re-use this article for personal use and teaching without any further permission.

Please cite this article as follows (you will need to access the article online to obtain the date of publication).

Boldt BM, Nguyen D. Post-traumatic intra-testicular haematoma may mimic a neoplasm or abscess on ultrasound. BMJ Case Reports 2010;

10.1136/bcr.06.2010.3119, date of publication

Become a Fellow of BMJ Case Reports today and you can:

- Submit as many cases as you like

Enjoy fast sympathetic peer review and rapid publication of accepted articles

- Access all the published articles

- Re-use any of the published material for personal use and teaching without further permission

For information on Institutional Fellowships contact consortiasales@bmjgroup.com

Visit casereports.bmj.com for more articles like this and to become a Fellow 